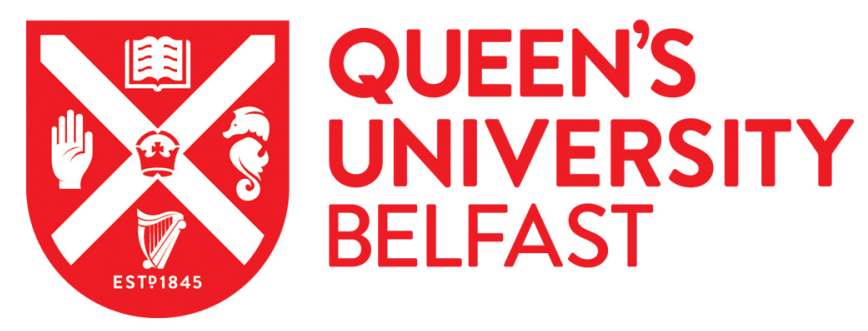

\title{
Constituency pressures on committee selection: Evidence from the Northern Ireland Assembly and Dáil Éireann
}

Raymond, C. D., \& Holt, J. (2017). Constituency pressures on committee selection: Evidence from the Northern Ireland Assembly and Dáil Eireann. Parliamentary Affairs. https://doi.org/10.1093/pa/gsx002

Published in:

Parliamentary Affairs

Document Version:

Peer reviewed version

Queen's University Belfast - Research Portal:

Link to publication record in Queen's University Belfast Research Portal

Publisher rights

() The Author 2017. Published by Oxford University Press on behalf of the Hansard Society.

This work is made available online in accordance with the publisher's policies. Please refer to any applicable terms of use of the publisher.

\section{General rights}

Copyright for the publications made accessible via the Queen's University Belfast Research Portal is retained by the author(s) and / or other copyright owners and it is a condition of accessing these publications that users recognise and abide by the legal requirements associated with these rights.

Take down policy

The Research Portal is Queen's institutional repository that provides access to Queen's research output. Every effort has been made to ensure that content in the Research Portal does not infringe any person's rights, or applicable UK laws. If you discover content in the Research Portal that you believe breaches copyright or violates any law, please contact openaccess@qub.ac.uk. 


\section{Title}

Constituency pressures on committee selection: Evidence from the Northern Ireland Assembly and Dáil Éireann

\section{Running head}

Constituency pressures on committee selection

\section{Original article}

Christopher D. Raymond

School of History, Anthropology, Philosophy, and Politics; Queen's University Belfast;

Belfast, United Kingdom

Jacob Holt

Department of Political Science; Columbus State University; Columbus, USA

\section{Corresponding author}

Dr C.D. Raymond; School of History, Anthropology, Philosophy, and Politics; Queen’s

University Belfast; Belfast, United Kingdom; C.Raymond@qub.ac.uk

\section{Acknowledgements}

An earlier version of this paper was presented was presented at the 2016 annual meeting of the Political Studies Association of Ireland in Belfast, Northern Ireland.

\section{Funding Declaration}

The production of this manuscript was not supported by any external funding.

\section{Conflicts of Interest}

The authors are unaware of any conflicts of interest. 


\section{CONSTITUENCY PRESSURES ON COMMITTEE SELECTION: EVIDENCE FROM THE NORTHERN IRELAND ASSEMBLY AND DÁIL ÉIREANN}

Most previous research examining selection to committees assumes constituency pressures leading representatives to seek committee assignments dealing with their constituents' particularistic interests that improve their re-election prospects - are incompatible with disciplined parties, which may prevent such personal vote-seeking behaviour in order to preserve the party's brand. In contrast, we argue parties will support committee assignments promoting members' re-election chances because parties benefit from their members' reelection. Analysing two legislatures with highly disciplined parties and electoral systems encouraging personal vote-seeking - the Northern Ireland Assembly and Dáil Éireann - our analysis suggests constituency pressures increase the chances of selection to committees enhancing members' re-election prospects.

Cartel theory, committee selection, constituency pressures, distributive theory 
Committees are widely viewed not only as the primary loci of activity in most legislatures, but also as essential for parliaments to influence policy independently of governments (Mezey, 1979; Mattson and Strøm, 1995). Accordingly, a considerable body of research examines selection to legislative committees. Much of this literature suggests that members will seek to be appointed to committees affecting their re-election interests. According to distributive theory, representatives seek selection to committees with jurisdiction over policies related to their constituents' economic interests and use their positions on these committees to increase their re-election chances (Mayhew, 1974; Shepsle, 1978). This theory is supported by a sizeable body of this research, though one that is largely concentrated on US legislatures (Weingast and Marshall, 1988; Hall and Grofman, 1990; Londregan and Snyder, 1994; Adler and Lapinski, 1997; Adler, 2000; Frisch and Kelly, 2004).

While the literature examining selection to committees outside the US is growing, distributive theory faces challenges when applied outside the US (see, e.g., Hansen, 2011). Chief among them is that parties outside the US tend to be more tightly disciplined, and previous research argues that parties will limit the extent to which self-interested members seeking to represent their constituents’ parochial interests are selected to committees dealing with those interests (Cox and McCubbins, 1993). Thus, previous research leads to contradictory expectations: while distributive theory predicts that members will self-select onto committees dealing with issues relevant to their constituents' interests, other research suggests the influence of constituency pressures on committee selection is incompatible with strong, disciplined parties seeking to protect against such influences, which might distract from the party's agenda and undermine the party brand.

In this paper, we analyse whether distributive theory is incompatible with disciplined parties, or whether constituency pressures influence selection to committees even in 
legislatures with strong parties. In line with distributive theory, we argue that constituency pressures will influence committee selection even in legislatures with disciplined parties. To test this argument, we focus on two legislative chambers with strong, disciplined parties: the lower house in the Irish Oireachtas (Parliament), Dáil Éireann, and the unicameral Northern Ireland Assembly. While the disciplined parties in both legislatures may work to prevent constituency pressures from influencing committee selection, members of both chambers are elected using the single-transferable vote (STV) system. The ability to rank candidates in STV systems encourages the sort of personal vote-seeking behaviour that characterises legislatures in the US (Martin, 2010a; André, Depauw, and Martin, 2016). As a result, STV encourages members in both houses to seek appointment to committees furthering their reelection prospects. Because personal vote seeking increases the chances members will be reelected, parties have an incentive to support such behaviour. Thus, examining committee selection in these two legislatures presents an interesting test of the compatibility of distributive theory and strong parties (and under electoral rules seldom studied in the committee selection literature).

In the next section, we examine previous literature regarding selection to committees. Following that, we discuss committees in the Dáil and Assembly and explain both the pressures leading TDs (members of Dáil Éireann known in Irish as Teachtaí Dála) and MLAs (members of Northern Ireland's Legislative Assembly) to seek selection to committees that benefit their re-election interests and those forces that might prevent these constituency pressures from influencing section to committee. After that, we outline the details of our research strategy. Following that, we analyse the impact of constituency pressures on committee selection. A final section discusses the implications of the findings for the literature on legislative organisation and committee membership.

\section{Models of committee selection}


One prominent theory of legislative organisation, distributive theory, holds that members will seek to serve on committees addressing their constituents' economic interests (Mayhew, 1974; Shepsle, 1978). For example, legislators in the US House of Representatives from agricultural districts will seek assignment to the Agriculture Committee, while members with military installations in their districts will seek assignment to the Armed Services Committee. In essence, members trade influence in policy areas that do not affect their re-election chances for influence over policy that does.

Committees allow members to engage in two activities Mayhew (1974) argues help members win re-election: credit claiming and position taking. Credit claiming is when members claim credit for delivering goods from the government to their districts, even if the member is not actually responsible for the district receiving the good. Committees give members chances to claim credit by giving them a greater opportunity to secure 'pork' projects for their districts. This allows members to show their constituents that they are producing tangible goods. Also, being on these committees allows members to claim credit for goods delivered by bureaucratic agencies, even when the legislator was in no way responsible for delivering the good. This happens because bureaucratic agencies allow members to claim credit because the agencies want to maintain good relations with representatives (who have influence over the agency’s funding and jurisdiction).

Committees also allow members to engage in position taking. Position taking occurs when members publicly take a position on issues. Committees provide several opportunities for members to take public positions. First, committees hold hearings on many issues. This allows members to make official statements on their positions. Second, committees take many votes on bills that members would not get the opportunity to vote for on the floor. These votes also allow members the opportunity to take public positions on the issues and signal to voters that they are working on behalf of constituents to protect their interests. 
Members engage in position taking and credit claiming in order to develop personal votes, which are votes candidates receive based on their individual characteristics or record (Cain, Ferejohn, and Fiorina, 1987). There are several ways members can develop personal votes. Undertaking casework (Cain, Ferejohn, and Fiorina, 1987; Heitshusen, Young, and Wood, 2005), delivering particularized goods (i.e. pork) to the district (Stein and Bickers, 1994; Bickers and Stein, 1996), and maintaining regular contact with constituents (Fenno, 1978) are some of the ways members can develop personal votes. Although members can develop personal votes in several ways, most of these mechanisms revolve around developing reputations among constituents for providing benefits or services to the district. These personal votes help members win re-election, especially during elections which are difficult for their party (Mann 1978). Committees are a useful mechanism for developing personal votes because they allow members the ability to claim credit - justifiably or not - for particularized goods in their district and to take public positions that might earn them personal votes. Resulting from the pressures placed on members by their constituents seeking to have their economic interests represented, members will seek selection onto committees with jurisdiction over policies related to the economic interests of members’ constituents in order to take positions on and claim credit for policies related to these interests that may win them personal votes.

Considerable research has tested the implications of distributive theory regarding selection to committees in the US. While many studies of the US Congress find evidence in favour of distributive theory (Weingast and Marshall, 1988; Hall and Grofman, 1990; Londregan and Snyder, 1994; Adler and Lapinski, 1997; Adler, 2000; Frisch and Kelly, 2004), most studies of American state legislatures do not (Overby and Kazee, 2000; Overby, Kazee, and Prince, 2004). One shortcoming with most research testing distributive theory is that the measures employed are based on roll-call votes and do not examine the influence of 
constituency pressures that give rise to personal vote-seeking behaviour. Whether scholars use interest group ratings (e.g., Weingast and Marshall, 1988; Hall and Grofman, 1990; Krehibel, 1990) or ideology measures like DW-NOMINATE (e.g., Cox and McCubbins, 1993; Londregan and Snyder, 1994) to determine whether members with similar preferences are more likely to be selected to committees enhancing their chances of re-election than members not facing such pressures, the conclusions reached in these studies are limited by the use of roll-call vote-based measures. For one, roll-call votes are based on a selective list of votes (e.g., Carrubba et al., 2006), which undermines their use as unbiased measures of preferences (Clinton, 2012). Additionally, such roll-call vote-based studies test for the impact of ideological extremity on committee selection when this does not accurately reflect the predictions of distributive theory. Instead, distributive theory argues members are motivated to serve on committees whose jurisdictions serve their constituents' economic interests (Mayhew, 1974; Rundquist and Ferejohn, 1975; Adler and Lapinski, 1997; Adler, 2000).

Instead of using roll-call votes to measure members’ preferences for a committee, a more direct way of examining the impact of constituency pressures on committee selection is to use census data measuring the economic interests of members' constituents. Unlike rollcall votes measuring members’ own voting behaviour, census-based measures more directly measure the incentives legislators have to seek committee assignments that benefit their constituents. Accordingly, studies using census-based measures find clearer evidence that constituency preferences influence committee selection in the US Congress than studies using other measures (Adler, 2000; Adler and Lapinski, 1997; Frisch and Kelly, 2004). To the extent such measures have been applied to study committee selection outside the US, these studies have also found evidence of constituency pressures influencing committee selection (Stratmann and Baur, 2002; Raymond and Holt, 2014). 
While there are reasons to expect that personal vote-seeking representatives may seek committee assignments in line with the predictions of distributive theory, cartel theory holds that party leaders will not allow members from their party ranks with particularistic interests to serve on committees enhancing their personal chances of re-election. This theory argues legislatures are organized to help the majority party pass its legislative agenda. Under this theory, party leaders do not allow members with particularistic interests to self-select onto committees enhancing their chances of re-election because committees composed of such members may interfere with the majority party’s ability to pass its agenda due to the possibility that such committees might have different policy preferences from the party (Cox and McCubbins, 1993, 2005). As a result, this theory predicts that the selection of members with particularistic interests to committees enhancing their re-election chances should be rare, particularly on committees impacting the party brand across the country (Cox and McCubbins, 1993, p.193).

Given that many parties outside the US are more cohesive and disciplined than American parties, cartel theory would predict weaker constituency effects on committee selection in legislatures outside the US. While most view distributive theory as incompatible with strong, disciplined parties, some recent research has found evidence of constituency pressures affecting committee selection in countries with more cohesive and disciplined parties (Stratmann and Baur, 2002; Raymond and Holt, 2014). If constituency pressures do indeed affect committee selection in legislatures with more disciplined parties, then this would call into question the notion that distributive theory is incompatible with strong parties.

\section{Committee selection with disciplined parties}

In this paper, we examine committee selection in the two legislatures on the island of Ireland: Dáil Éireann and the Northern Ireland Assembly. These houses are interesting cases because they allow us to test the compatibility of distributive and cartel theories. TDs and 
MLAs are elected via the single-transferable vote (STV) system. Similar to other candidatecentred electoral systems (Carey and Shugart, 1995; André, Depauw, and Martin, 2016), the ability to rank candidates according to preference in STV systems encourages TDs and MLAs to seek appointment to committees that further their re-election prospects - in line with distributive theory (Martin, 2010a). While the STV system provides TDs and MLAs with incentives to pursue their constituents’ particularistic interests, this behaviour may be limited by the gatekeeping role played by parties when determining which members to select to committee. Parties in both the Dáil and the Assembly operate as highly cohesive organisations that are tightly disciplined by their leaders, who punish defectors (Gallagher, 2010), which would lead one to expect - per cartel theory - that constituency pressures do not influence committee selection. Because the personal vote-seeking behaviour promoted by STV contrasts with the strong party-centred environments in the Dáil and Assembly, examining committee membership in these two institutions presents an interesting test of the compatibility of distributive theory and strong, disciplined parties.

In contrast to cartel theory, we expect the predictions of distributive theory to be compatible with strong parties in candidate-centred electoral systems like STV. While STV provides TDs/MLAs incentives to develop personal votes, it also gives parties an incentive to let them do so. Because the ballot is structured so that voters rank-order candidates, not parties, TDs and MLAs can develop personal votes among their constituents. Developing personal votes can aid re-election, especially in elections when one’s party fares poorly. At the same time, members developing personal votes do not take away votes from other candidates the party is running in the district because 'surplus' votes for an elected candidate are redistributed to lower preferences. When TDs/MLAs develop good reputations among their constituents, it may even help their parties win additional seats because the party's reputation in the district may also be positively affected when their incumbent members' 
reputations rise. Because government parties possess tools to enforce discipline among caucuses composed of members with diverse preferences, which minimise the chances of being defeated on the floor (Cox and McCubbins, 2005), the consequences of constituency pressures impacting committee selection are easily offset. Moreover, even if personal voteseeking behaviour undermined a party's agenda, the costs of constituency pressures would be offset by controlling the agenda, the probability of which is increased by members winning re-election. Thus, STV encourages parties to allow members to develop personal votes because not only can personal votes help TDs'/MLAs’ re-election efforts, but it may also help parties gain additional seats in the chamber.

While cartel theory predicts that parties will play a gatekeeping role, preventing members facing constituency pressures from receiving committee assignments benefitting their constituents' interests, the practice of committee selection in both houses contradicts many of cartel theory's expectations. Like in most legislatures, the number of seats parties have on committees in both houses is proportional to their seat shares (Hansen, 2011; Wilford and Wilson, 2001). Committee members in the Assembly are largely self-selecting, although some are assigned by party whips (Wilford and Wilson, 2001). Although some members are assigned by whips, this is likely to occur for committees that lack distributive potential, since members are unlikely to seek assignment to committees when committee service does not benefit them. Though the allocation of committee assignments in the Dáil occurs through parties after TDs make their assignment preferences known to party leaders (Hansen, 2011), in practice, TDs are able to move easily onto committees if they want. ${ }^{1}$ Thus, parties play less of a role in preventing TDs and MLAs from receiving committee assignments that benefit their constituents' interests than cartel theory would predict.

\footnotetext{
${ }^{1}$ On this point, we are indebted to the insights provided to us by Art O’Leary (Secretary General to the President).
} 
While cartel theory emphasises the concerns parties have with the particularistic, personal vote-seeking of their members, there are institutional arrangements in both chambers allowing parties to control the agenda even if members self-select onto committees to enhance their own prospects of re-election. Although committees in the Dáil have accumulated greater scrutiny powers since 1982 - particularly after the coalition agreement at the start of the $30^{\text {th }}$ Dáil to strengthen the role of committees, with committees today linked more closely to one or more government ministries than in the past, which gives the committees the ability to both monitor the ministries the committee is linked with and scrutinise legislation and executive action in that policy area (Martin, 2010b) - the government, not committees, ultimately controls the agenda, and thus, members' particularistic behaviour is not necessarily costly to the party agenda or brand. If committees stray too far from the government's preferences, committee decisions can be reversed on the floor. The fact any decision made by a committee can be reversed by the whole Dáil makes assigning TDs facing constituency pressures less costly to parties. While committees in the Assembly are more able to influence policy than their counterparts in the Dáil (Osborne, 2002), parties still maintain an ability to check committees if they move in a direction the party does not prefer. In the Assembly, parties with the support of at least 30 of the 108 MLAs can effectively block a bill using a 'petition of concern', which requires majority support on both sides of the Protestant-Catholic divide for a bill to pass - a tool that parties have arguably abused (Conley and Dahan, 2013). Therefore, if committees stray too far from a party's preference, parties have the ability to block this legislation without the aid of other parties in their coalition. Thus, in both legislatures, committees pose little threat to governments’ agendas, and as a result parties may be willing to tolerate the committeeseeking behaviour by TDs/MLAs.

If committees in both houses do not have significant powers to shape agendas, one is 
left asking what incentives TDs/MLAs have to seek selection. While Irish committees are generally viewed as weak because they have few resources with which to influence policy (Martin, 2010b), committees are still attractive for several reasons. For one, committees allow members to engage in position taking during public committee debates - in addition to the prestige factor to be gained from being seen by constituents working on their behalf on these committees. Additionally, they allow members an opportunity to claim credit for voicing the concerns of constituents on committee debates in ways that may influence the government and/or their party leaders to support distributive action (e.g., targeted spending) for their constituents. Even though pork is rarely distributed through Irish committees, ministers are more sensitive to committee members’ preferences (given the oversight capacity of committees), as are civil servants (who must act in accordance with ministers' wishes), which in turn gives committee members more influence over policy than other TDs/MLAs. ${ }^{2}$ Whenever government spending benefits their constituents, members can claim credit (rightly or wrongly) for this by dint of their association with and actions on the relevant committee; whenever there is dissatisfaction with government action, being on the committee gives one a platform to claim credit as someone who can deliver the desired change (rightly or wrongly) in the future. Finally, although the impact of these actions taken on committee may only have a marginal impact on members’ re-election chances, TDs/MLAs at all levels of electoral security may seek assignment to committees that could perceivably impact their chances of re-election because they feel electorally insecure at any margin of victory (like their counterparts in the US: see Mann, 1978). Thus, even if they are often merely symbolic, these actions may help members' re-election chances, and thus, members have incentives to pursue committee assignments that advance their re-election interests by helping them to claim credit and take positions on particularistic issues.

\footnotetext{
${ }^{2}$ We thank one of the anonymous referees for suggesting this point to us.
} 


\section{Research design}

To determine whether constituency pressures impact the selection of TDs and MLAs to committees in Dáil Éireann and Northern Ireland Assembly, we examine selection to committees dealing with agricultural issues. We focus on selection to agricultural committees for two reasons. One is an issue of comparability. Both the Dáil and the Assembly have committees dealing explicitly with agricultural issues. While other committees likely have distributive potential that might lead TDs/MLAs to seek assignment to these committees, agricultural issues are the only measurable distributive issue common to committees in both houses. Comparing the two legislatures allows us to determine the reliability of any finding regarding the relationship between constituency pressures and committee assignments under STV rules with strong parties.

Additionally, focusing on these committees addresses concerns with data availability. On the one hand, examining selection to agricultural committees lends itself to valid and reliable measurement of relevant constituency pressures, as census data measuring agricultural interests at the constituency level are available for both houses. While constituents may pressure their representatives to pursue selection to other committees in order to pursue their particularistic interests, census data measuring constituency pressures are harder to come by.

To this end, we gather data on each member of each house during three terms. In the Dáil, we examine data from the three most recent completed legislative terms: the $29^{\text {th }}$ (20022007), 30 ${ }^{\text {th }}$ (2007-2011), and $31^{\text {st }}$ (2011-2016) Dáils. In the Northern Ireland Assembly, we examine three of the four completed legislative terms: the first (1998-2003), third (20072011), and fourth (2011-2016) legislative assemblies. (The second assembly did not meet due to the inability of the parties to form a government.) TDs and MLAs selected to an agriculture committee during a particular term are coded one, and zero otherwise. 
We examine these legislative terms due to the availability of data measuring constituency pressures. Specifically, we use data from the Irish Central Statistics Office (specifically, the censuses of 2002, 2006, and 2011) and the Northern Ireland Statistics and Research Agency (specifically, the 2001 and 2011 censuses). Constituency pressures are measured as the percentage of the constituency employed in agriculture, forestry, and fishing. In both legislatures, we standardise these variables to range from zero (the lowest level of constituency pressure) to one (the highest level). We standardise these variables separately for each legislative term in order to account for the fact that distributive theory predicts that committee decisions are based on the constituency demands relative to each term. That is, while the distribution of values of agricultural employment differ from term to term based on fluctuations in employment and the configuration of electoral boundaries, this measurement strategy accounts for the predictions made by distributive theory that TDs/MLAs from constituencies with higher levels of agricultural employment relative to the distribution of values in a particular term will be more likely to seek appointment to agricultural committees than TDs/MLAs facing fewer such pressures from their constituents.

We also include several control variables to isolate the effects of constituency pressures. For one, we account for the possibility that the floor in both the Dáil and Assembly may seek to select TDs and MLAs with experience and subject-specific knowledge relating to agriculture to committees dealing with such issues to help the committee produce unbiased, high-quality information that aids the legislature in producing good policy - as predicted by informational theory (Krehbiel, 1991). Using the biographical information provided on both houses’ websites, as well as TDs’ and MLAs’ personal websites, we included a variable coded one for TDs and MLAs who claimed occupational backgrounds in agriculture and zero otherwise.

We also include several variables to account for other hypotheses supported by 
previous literature (see Hansen, 2011). ${ }^{3}$ For one, we include a variable coded one for TDs and MLAs who have experience as ministers in previous terms, and zero otherwise. This variable accounts for the finding that TDs with previous ministerial experience are significantly less likely to be selected to committee than TDs without such experience. We also include a variable measuring the seniority of TDs to account for the possibility that more senior TDs and MLAs are more likely to be selected to committees than more junior members. This variable measures the number of years between the end of each term and the year TDs/MLAs were first elected to their respective houses.

We also include a variable measuring TDs’/MLAs’ constituency-level first preference vote shares in the previous election relative to the quota needed to be elected in their constituencies. In keeping with research showing that less electorally secure representatives exert more constituency effort than less secure representatives (Heitshusen, Young, and Wood, 2005; André, Depauw, and Martin, 2015), TDs/MLAs with larger ratios of first preference votes to electoral quotas - reflecting greater electoral security - should be less likely to seek assignment to committee than less-secure TDs/MLAs. To account for the possibility that electoral security conditions the effects of constituency pressures, we interact agricultural employment with TDs’/MLAs’ first preference vote/quota ratios.

The desire to reach committees may also be influenced by intra-party competition at the constituency level. TDs contest elections in constituencies electing between three and five seats, while MLAs all compete in constituencies electing six seats. The more TDs/MLAs have to compete alongside fellow candidates of the same party (i.e. the more

\footnotetext{
${ }^{3}$ We also examined whether there was a gendered dimension to committee selection leading to a lower probability of women being selected to agricultural committees. However, we found no evidence that women were any less likely to be selected to committee than men and, thus, do not include a control for gender.
} 
candidates of the same party competing per constituency), the more TDs/MLAs will need to distinguish themselves among their constituents in order to develop personal votes, and thus the more likely TDs/MLAs will seek committee assignments that increase their chances of reelection. To account for this possibility, we include a variable measuring the number of copartisan candidates competing in the previous election and interact this variable with agricultural employment. ${ }^{4}$

To account for differences in the probability of being selected to agricultural committees across the different terms, we treat the first legislative terms in each house as the baseline and include dummy variables for subsequent terms. To account for possible differences in the effects of constituency pressures across the three terms, we interact constituency pressures with these dummy variables. This is particularly important for the analysis of committee selection in the Dáil, where differences in the remit and powers of committees dealing with agricultural issues over time might condition the effect of constituency pressures on selection to committees. ${ }^{5}$

\footnotetext{
${ }^{4}$ Given the variation in the number of seats per constituency in the Dáil, we also examined the impact this variation had on the relationship between constituency pressures and committee selection. The results of these analyses provide little evidence to suggest that the number of seats conditions the effects of constituency pressures on committee selection. ${ }^{5}$ In the $29^{\text {th }}$ Dáil (2002-2007), agricultural issues were addressed by the Agriculture and Food committee; in the 30 ${ }^{\text {th }}$ Dáil (2007-2011), this committee was known as Agriculture, Fisheries, and Food; in the 31 $1^{\text {st }}$ Dáil (2011-2016), the name changed to Agriculture, Food, and the Marine. None of these three iterations overlapped perfectly with the duties of the Minister of State for Food and Horticulture (2002-2011) or the Minister of State for Food, Horticulture, and Food Safety (2011-2016).
} 


\section{Results}

We estimate two models for each house: one model includes all of the variables listed above, while another model omits the interaction terms in order to compare with the saturated models. To estimate these models, we use logistic regression, clustering standard errors by TD/MLA to adjust standard errors in response to the fact that many TDs/MLAs appear multiple times in the data set. The results of our logistic regression models appear in Table 1.

\section{Table 1 about here}

Beginning with the impact of the constituency pressure variables, the results in models 1 and 3 (which omit the interaction effects) indicate that TDs and MLAs representing constituencies with more people employed in agriculture, forestry, and fishing have a higher probability of being selected to agriculture committees. Both coefficients are positive and statistically significant. While other variables - namely, the variable measuring the implications of informational theory (whether TDs/MLAs worked in agriculture) - reach statistical significance, these results suggest that constituency pressures influence selection to committee in both houses. In contrast to cartel theory, these results suggest constituency pressures can influence committee selection in legislatures with strong, disciplined parties.

To see the effects of constituency pressures more clearly, Figures 1 and 2 present the predicted probabilities of being selected to agricultural committees in both houses across the range of each constituency pressure variable. Beginning with the effects of constituency pressures in the Dáil, which we present in Figure 1, we see that the probability of being selected to agricultural committees increases from just over 12 per cent at the lowest levels of agricultural employment (and, thus, the lowest levels of constituency pressure) to nearly 54 per cent in constituencies with the highest levels of agricultural employment. Similar, though not as dramatic effects emerge when looking at the Assembly, which can be seen in Figure 2. In the Assembly, we see that the predicted probability of being selected to the Agriculture 
and Rural Development Committee increases from just under six per cent in constituencies with the lowest percentage of constituents employed in agricultural to just under 30 per cent in constituencies with the highest levels of agricultural employment. ${ }^{6}$ Thus, and in keeping with distributive theory, these results demonstrate that TDs and MLAs facing the greatest constituency pressures are the most likely to be assigned to agriculture committees. While the focus on agricultural committees - which often display evidence of constituency effects on members' selection in other legislatures - might predispose the results towards finding that constituency pressures impacted committee selection, these findings nevertheless suggest that constituency pressures may impact selection to other committees with distributive potential when representatives face incentives to cultivate personal votes.

Figures 1 and 2 about here

Turning to the results of the models including interaction effects, the results of model fit tests comparing the likelihood ratios of the two sets of models suggest that the interaction effects included in each model fail to provide significant improvements in model fit over models 1 and 3. Thus, there is little evidence to suggest that the effects of constituency pressures on committee selection are conditioned by electoral security, intra-party competition for personal votes, or the legislative term. As a result, the results from the two unsaturated models are to be preferred.

The lack of evidence in favour of significant interaction effects conditioning the impact of constituency pressures on committee selection leads to several interesting conclusions. For one, the results suggest that less electorally secure TDs/MLAs are no more

\footnotetext{
${ }^{6}$ One potential reason for the comparatively weaker effects of constituency pressures in the Assembly may be due to the smaller number of constituencies in Northern Ireland. Whereas TDs were elected in around forty constituencies, MLAs are elected in 18 constituencies. We are thankful to one of the anonymous referees for this suggestion.
} 
likely to be selected to committees enhancing their re-election prospects than more electorally secure TDs/MLAs. This suggests the possibility that TDs and MLAs, like members of the US Congress, feel unsafe at any margin (Mann, 1978), and thus even electorally secure TDs/MLAs pursue committee assignments that improve their chances of re-election. While this finding may not be surprising to observers of Dáil elections, where several poll-toppers in one election have gone on to drop off or even lose in the next election when their party's fortunes changed (see, e.g., Kavanagh, 2011), it only underscores the importance for representatives to develop personal votes through committee work to ensure their personal electoral security. Additionally, the results suggest that TDs/MLAs facing more intra-party competition for the attention and personal votes of constituents are no more likely to be selected to committee than TDs/MLAs facing less intra-party competition.

Finally, the fact that legislative terms do not significantly condition the effect of constituency pressures is also interesting. While the powers of the Agriculture and Rural Development Committee have not changed much over the past two decades, the fact that committees in the Dáil have suggests that the degree to which constituency preferences impact individual representatives' chances of being selected to agricultural committees has not been affected in any significant way by the efforts to strengthen committees over the last two terms. In other words, increasing the powers of Dáil committees has not made committees more attractive venues for TDs, and thus increased committee strength has not changed the basic impact of constituency pressures.

In sum, even after controlling for all of the variables measuring the alternative hypotheses discussed above, the results continue to show that the variables measuring constituency pressures remain statistically significant and positively associated with selection to agricultural committees in both the Dáil and the Assembly. In keeping with distributive theory, the results presented here suggest that TDs and MLAs from constituencies with more 
people employed in agriculture - which puts pressure on representatives to pursue distributive goods on behalf of these constituents - are selected to agricultural committees that allow them to pursue their constituents' interests. Taken together, these results suggest constituency pressures can exert significant influence on elected representatives that compels them to seek selection to agricultural committees even in legislatures with strong, disciplined parties.

\section{Conclusion}

In this paper, we have examined whether constituency pressures impact committee selection in legislatures with strong, disciplined parties using the examples provided by the two legislatures on the island of Ireland. In addition to being understudied relative to US legislatures, studying selection to committees in these two legislatures is interesting because (1) parties in both legislatures are tightly disciplined, which cartel theory suggests should prevent the appearance of distributive effects on committee selection, and (2) despite this, TDs and MLAs face incentives from the STV system used in elections to both houses to cultivate personal votes in order to enhance their personal chances of re-election. This tension between strong, disciplined parties and an electoral system that promotes personal vote-seeking allows us to test whether distributive theory's implications can be seen in legislatures with strong parties.

Our analysis shows that, at least on committees dealing with agricultural issues, there is evidence of constituency pressures on committee selection in both houses. In keeping with distributive theory, and in contrast to the expectations of cartel theory, TDs and MLAs from constituencies with more people employed in agricultural occupations - and therefore facing the greatest pressures to seek selection to these committees - are more likely to be selected to committees dealing with agricultural issues. While our analysis is limited to one type of constituency pressure and one type of committee, these results suggest the possibility that 
constituency pressures influence selection to committees dealing with other issues. With adequate data similar to the data used here, our results suggest that constituency pressures may influence selection to committees that enhance members' re-election chances.

Our results offer other interesting findings that are relevant to future research on committees cross-nationally. For one, while previous literature would expect less electorally secure representatives to exert more constituency effort by seeking committee assignments favourable to members’ re-election interests (Heitshusen, Young, and Wood, 2005; André, Gallagher, and Sandri, 2014; André, Depauw, and Martin, 2015), our results suggest that less electorally secure TDs/MLAs are no more likely to be selected to committee than more electorally secure representatives. While most literature would predict that this finding occurs due to parties’ efforts to prevent constituency effects on committee assignments, selecting only the most loyal members to sit on committee, selection to committees in the Assembly and Dáil is not as limited by parties as in US legislatures - perhaps due to the smaller numbers of MLAs and TDs needed to fill these roles. The null findings regarding the impact of electoral security suggest that TDs/MLAs may pursue committee assignments benefitting their chances of re-election because they feel unsafe at any margin of electoral security (similar to their American counterparts: see Mann, 1978). Although this finding should be subjected to greater scrutiny to confirm whether the results seen here are generalisable to other legislatures, this finding suggests that even if more electorally-secure legislators exhibit less constituency effort, constituency pressures to deliver particularistic goods may still compel them to pursue committee assignments that benefit their constituents - and in turn themselves as well. Given that similar personal vote-seeking motivations exist in other electoral systems besides first-past-the-post and STV (Carey and Shugart, 1995; André, Depauw, and Martin, 2016), we would expect similar results to those seen here in other candidate-centred electoral systems. This, however, needs to be explored in future 
research.

One final point to note is that our results suggest that constituency effects on committee selection and strong parties can coexist. This conclusion has important implications for previous studies of committee selection in the US, where some previous research has suggested that parties may not allow committees to be composed of members with outlying preferences due to the threats to the party brand and party unity presented by personal vote-seeking among individual members (Cox and McCubbins, 1993). Because parties seek to win enough seats to form a government (alone or as part of a coalition), and because personal votes increase the chances their members will be re-elected, our results suggest parties may allow members to seek committee assignments that advance their constituents' particularistic interests - especially when these committee assignments are not fundamentally detrimental to the parties’ larger agendas (Cox and McCubbins, 1993, p.199) because such distributive behaviour enhances a party's chances of winning enough seats to enter government. Because parties’ primary goal is to win elections, and because parties in government possess tools to discipline their members and prevent the party from being defeated on floor votes (Cox and McCubbins, 2005), the threat to a party’s agenda posed by personal vote-seeking behaviour appears quite minimal and worth the price of winning control of government. 
Table 1 Logistic regression models of selection to agriculture committees in Dáil Éireann and Northern Ireland Assembly

\begin{tabular}{|c|c|c|c|c|}
\hline \multirow[b]{2}{*}{ Variables } & \multicolumn{2}{|c|}{ Dáil Éireann } & \multicolumn{2}{|c|}{ Northern Ireland Assembly } \\
\hline & 1 & 2 & 3 & 4 \\
\hline Agricultural employment & $2.12(0.41)^{* *}$ & $3.32(1.70)$ & $1.88(0.49)^{* *}$ & $0.46(1.81)$ \\
\hline Employment experience with agriculture & $0.98(0.31)^{* *}$ & $0.95(0.31)^{* *}$ & $1.52(0.66)^{* *}$ & $1.64(0.67)^{* *}$ \\
\hline Former minister & $-1.01(0.41)^{* *}$ & $-1.01(0.42)^{*}$ & $-0.79(0.69)$ & $-0.73(0.69)$ \\
\hline Seniority & $-0.00(0.02)$ & $-0.00(0.02)$ & $0.04(0.05)$ & $0.03(0.05)$ \\
\hline Electoral security & $0.33(0.54)$ & $0.42(0.88)$ & $-0.61(0.51)$ & $-1.78(0.88)^{*}$ \\
\hline \# of co-partisans contesting the constituency & $-0.04(0.13)$ & $0.19(0.28)$ & $-0.03(0.14)$ & $-0.17(0.24)$ \\
\hline $30^{\text {th }}$ Dáil// $3^{\text {rd }}$ Assembly & $-0.03(0.26)$ & $0.06(0.44)$ & $0.20(0.37)$ & $0.63(0.71)$ \\
\hline $31^{\text {st }}$ Dáil $/ 4^{\text {th }}$ Assembly & $-0.71(0.30)$ & $-0.03(0.57)$ & $0.88(0.48)$ & $1.90(0.75)^{* *}$ \\
\hline Agricultural employment $\times$ electoral security & & $-0.38(1.77)$ & & $2.46(1.70)$ \\
\hline Agricultural employment $\times \#$ of co-partisans & & $-0.42(0.43)$ & & $0.28(0.47)$ \\
\hline Agricultural employment $\times 30^{\text {th }}$ Dáil/ $/ 3^{\text {rd }}$ Assembly & & $-0.18(0.77)$ & & $-0.71(1.04)$ \\
\hline Agricultural employment $\times 31^{\text {st }}$ Dáil $/ 4^{\text {th }}$ Assembly & & $-1.29(0.93)$ & & $-1.95(1.16)$ \\
\hline Constant & $-2.12(0.52)^{* *}$ & $-2.65(0.91)^{* *}$ & $-2.38(0.62) * *$ & $-1.82(1.14)$ \\
\hline Likelihood Ratio $\chi^{2}$ Test $^{1}$ & - & 3.22 & - & 4.69 \\
\hline McFadden's $\mathrm{R}^{2}$ & 0.13 & 0.14 & 0.11 & 0.12 \\
\hline$\%$ correctly predicted & $79.29 \%$ & $78.11 \%$ & $79.32 \%$ & $79.01 \%$ \\
\hline n (TDs/MLAs) & $507(303)$ & $507(303)$ & $324(202)$ & $324(202)$ \\
\hline
\end{tabular}

${ }^{*} \mathrm{p}<0.05,{ }^{* *} \mathrm{p}<0.01$, two-tailed tests. ${ }^{1}$ Model comparison tests comparing the likelihoods of the two saturated models (models 2 and 4 ) with models 1 and 3 ; insignificant $\chi^{2}$ values suggest models 1 and 3 are preferred. 
Figure 1 Predicted probabilities of being selected to agriculture committees in Dáil Éireann

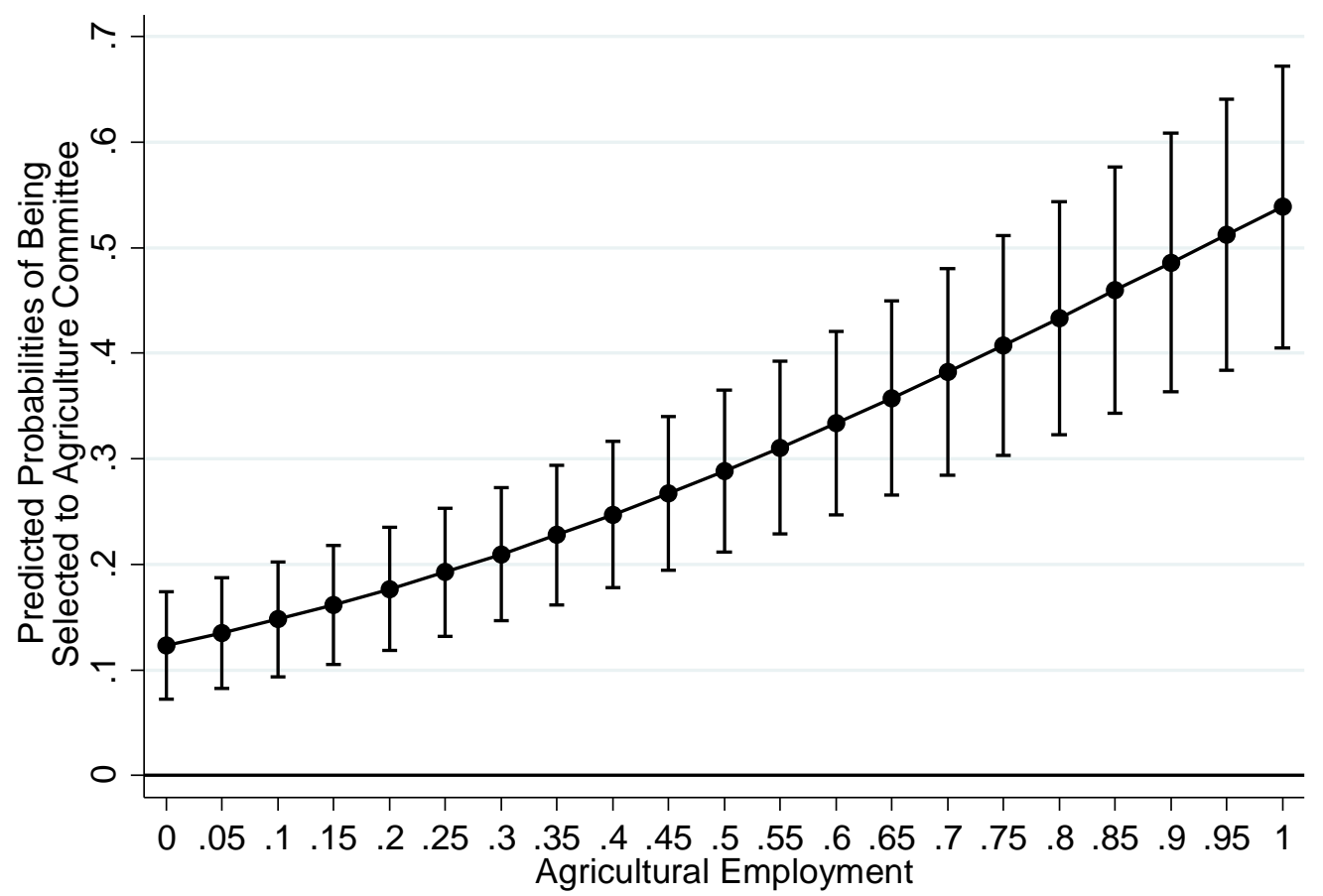

NB: bars represent $90 \%$ confidence intervals. 
Figure 2 Predicted probabilities of being selected to the Agriculture and Rural Development Committee in the Northern Ireland Assembly

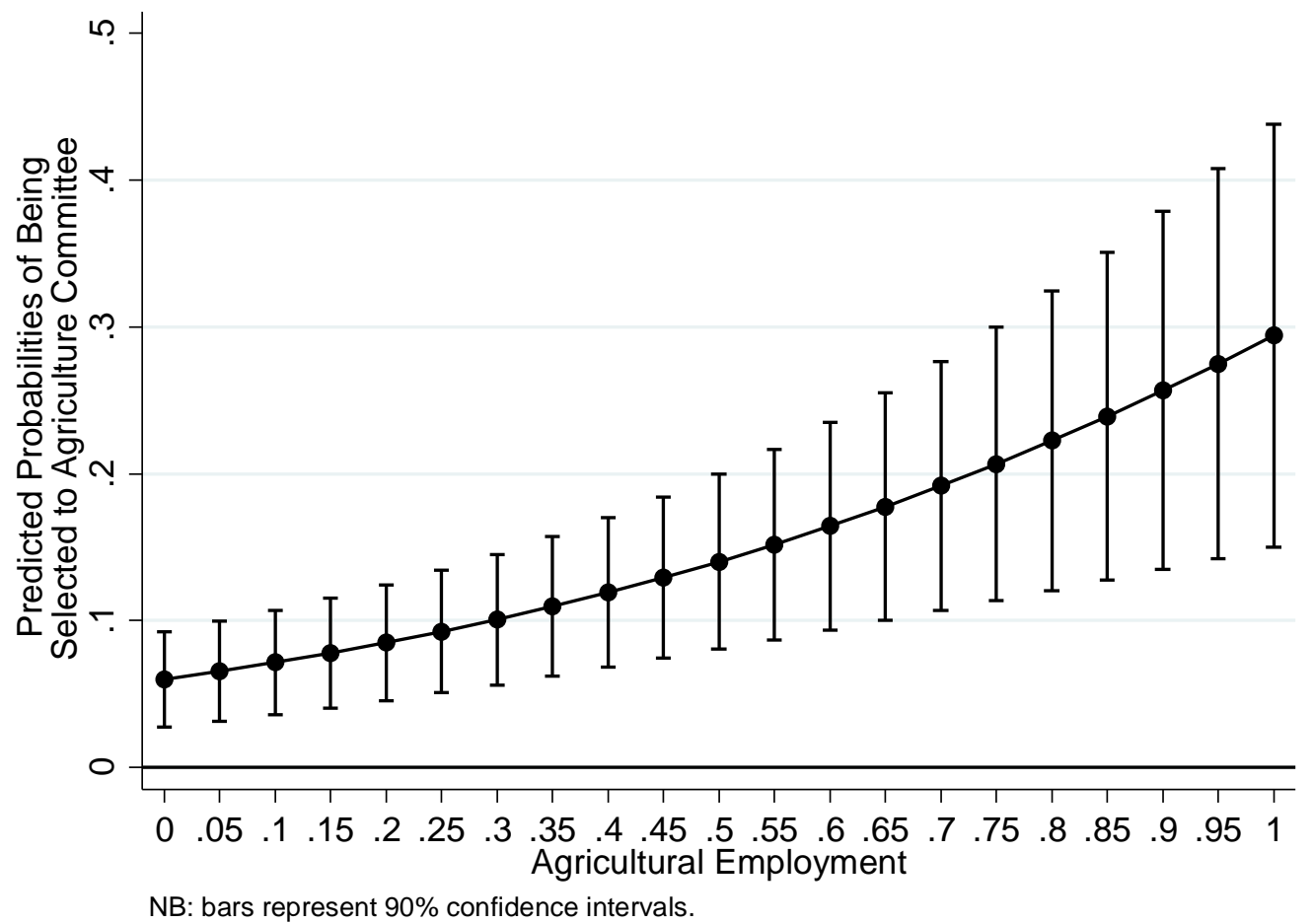




\section{References}

Adler, E.S. (2000) ‘Constituency Characteristics and the ‘Guardian’ Model of Appropriations Subcommittees, 1959-1998', American Journal of Political Science, 44, 104-114.

Adler, E.S., and Lapinski, J.S. (1997) ‘Demand-Side Theory and Congressional Committee Composition: A Constituency Characteristics Approach’, American Journal of Political Science, 41, 895-918.

André, A., Gallagher, M., and Sandri, G. (2014) ‘Legislators’ Constituency Orientation’ In Deschouwer, K. and Depauw, S. (eds.), Representing the People: A Survey Among Members of Statewide and Substate Parliaments, Oxford: Oxford University Press pp.166-187.

André, A., Depauw, S., and Martin, S. (2015) ‘Electoral Systems and Legislators’ Constituency Effort: The Mediating Effect of Electoral Vulnerability', Comparative Political Studies, 48, 464-496.

André, A., Depauw, S., and Martin, S. (2016) 'The Classification of Electoral Systems: Bringing Legislators Back In’, Electoral Studies, 42, 42-53.

Bickers, K.N., and Stein, R.M. (1996) 'The electoral dynamics of the federal pork barrel', American Journal of Political Science, 40, 1300-1326.

Cain, B., Ferejohn, J., \& Fiorina, M. (1987) The Personal Vote: Constituency Service and Electoral Independence. Cambridge: Harvard University Press.

Carey, J.M., and Shugart, M.S. (1995) 'Incentives to cultivate a personal vote: A rank ordering of electoral formulas', Electoral studies, 14, 417-439.

Carrubba, C.J., Gabel, M., Murrah, L., Clough, R., Montgomery, E. and Schambach, R., (2006) 'Off the record: Unrecorded legislative votes, selection bias and roll-call vote analysis’, British Journal of Political Science, 36, 691-704.

Clinton, J.D. (2012) 'Using Roll Call Estimates to Test Models of Politics’, Annual Review of 
Political Science, 15, 79-99.

Conley, R.S., and Dahan, C. (2013) 'Legislative Behaviour in the Northern Ireland Assembly, 2007-11: Conflict and Consensus in a Developing Consociational Democracy’, Political Studies, 61, 179-197.

Cox, G.W. and McCubbins, M.D. (1993) Legislative Leviathan: Party Government in the House. Berkeley: University of California Press.

Cox, G.W., and McCubbins, M.D. (2005) Setting the agenda: Responsible party government in the US House of Representatives. Cambridge: Cambridge University Press.

Fenno, R.F. (1978) Home Style: House Members in their Districts. Boston: Little, Brown, and Company.

Frisch, S.A. and Kelly, S.Q. (2004) 'Self-selection reconsidered: House committee assignment requests and constituency characteristics’, Political Research Quarterly, 57, 325-326.

Gallagher, M. (2010) 'Parliamentary parties and the party whips’ In M. MacCarthaigh and M. Manning (eds.), The Houses of the Oireachtas. Dublin: Institute of Public Administration pp.129-152.

Hall, R.L., and Grofman, B. (1990) 'The committee assignment process and the conditional nature of committee bias’, American Political Science Review, 84, 1149-1166.

Hansen, M.E. (2011) ‘A random process? Committee assignments in Dáil Éireann’, Irish Political Studies, 26, 345-360.

Heitshusen, V., Young, G., and Wood, D.M. (2005) 'Electoral Context and MP Constituency Focus in Australia, Canada, Ireland, New Zealand, and the United Kingdom', American Journal of Political Science, 49, 32-45.

Kavanagh, A. (2011) 'The fate of 2007’s poll toppers', accessed at https://adriankavanaghelections.org/2011/03/08/fate07gepolltoppers/ on 14 January 
Krehbiel, K. (1990) 'Are congressional committees composed of preference outliers?', American Political Science Review, 84, 149-163.

Krehbiel, K. (1991) Information and Legislative Organization. Ann Arbor: University of Michigan Press.

Londregan, J., and Snyder, J.M., (1994) ‘Comparing committee and floor preferences’, Legislative Studies Quarterly, 19, 233-266.

Mann, T.E. (1978) Unsafe at Any Margin: Interpreting Congressional Elections.

Washington, D.C.: American Enterprise Institute.

Martin, S. (2010a) 'Electoral rewards for personal vote cultivation under PR-STV', West European Politics, 33, 369-380.

Martin, S. (2010b) ‘The Committee System’ In MacCarthaigh, M. and Manning, M. (eds.), The House of the Oireachtas: Parliament in Ireland. Dublin: Institute of Public Administration pp.285-302.

Mattson, I., and Strøm, K. (1995) ‘Parliamentary Committees’ In Döring, H. (ed.), Parliaments and Majority Rule in Western Europe. Frankfurt: Campus Verlag pp. 249-307.

Mayhew, D. (1974) Congress: The Electoral Connection. New Haven: Yale University Press. Mezey, M.L. (1979) Comparative Legislatures. Durham: Duke University Press.

Osborne, R.D. (2002) 'Making a difference? The role of statutory committees in the Northern Ireland Assembly’, Public Administration, 80, 283-299.

Overby, L.M., and Kazee, T.A. (2000) 'Outlying committees in the statehouse: An examination of the prevalence of committee outliers in state legislatures', Journal of Politics, 62, 701-728.

Overby, L.M., Kazee, T.A., and Prince, D.W. (2004) 'Committee Outliers in State 
Legislatures’, Legislative Studies Quarterly, 29, 81-107.

Raymond, C. and Holt, J. (2014) 'Due North? Do American Theories of Legislative Committees Apply to Canada?’, Journal of Legislative Studies, 20, 174-192.

Rundquist, B.S., and Ferejohn, J.A. (1975) 'Observations on a Distributive Theory of Policymaking: Two American expenditure programs compared’ In Liske, C., Loehr, W., and McCammant, J. (eds.), Comparative Public Policy: Issues, Theories, and Methods, New York: Wiley pp.87-108.

Shepsle, K.A. (1978) The Giant Jigsaw Puzzle. Democratic Committee Assignments in the Modern House. Chicago: University of Chicago Press.

Stein, R.M., and Bickers, K.N. (1994) 'Congressional elections and the pork barrel’, Journal of Politics, 56, 377-399.

Stratmann, T. and Baur, M. (2002) 'Plurality Rule, Proportional Representation, and the German Bundestag: How Incentives to Pork-Barrel Differ across Electoral Systems’, American Journal of Political Science, 46, 506-514.

Weingast, B.R., and Marshall, W. J. (1988) 'The industrial organization of Congress; or, why legislatures, like firms, are not organized as markets', The Journal of Political Economy, 96, 132-163.

Wilford, R., and Wilson, R. (2001) A Democratic Design?: The Political Style of the Northern Ireland Assembly. London: Constitution Unit, School of Public Policy, UCL. 